\title{
КИТАЙ: РАЗВИТИЕ НАЦИОНАЛЬНОЙ ИННОВАЦИОННОЙ СИСТЕМЫ
}

\author{
(C) 2019 Гусарова Светлана Анатольевна \\ доктор экономических наук, доцент, ведущий научный сотрудник \\ Российский экономический университет имени Г.В. Плеханова, Россия, Москва \\ E-mail: s-gusarova@mail.ru
}

Автор провел исследование развития национальной инновационной системы Китая. Определил основные пути совершенствования этого процесса. Сделан вывод, что на рост инновационной экономики Китая влияет увеличение объема финансирования НИОКР. Установлено, что основными структурными элементами национальной инновационной системы Китая являются государственные организации, университеты, научно-исследовательские институты, научно-исследовательские подразделения компаний.

Ключевые слова: Китай, национальная инновационная система, финансирование НИОКР, развитие экономики.

\section{1. Введение}

Китай занимает ведущее место в мировой экономике. В 2018 году Китай (по данным МВФ) по объему ВВП (валового внутреннего продукта) находился на втором месте (после США) в мире (14,22 трлн. долл.). В то же время Китай был мировым лидером по объему ВВП по ППС (по паритету покупательной способности), его доля в мировом объеме составила 19,24\% [1]. Китай за последнее десятилетие достиг значительных успехов в развитии науки и техники, внедряя в производство инновации и высокие технологии.

Особый этап формирования национальной инновационной системы Китая начался в 2013 году, когда в результате решений XVIII Всекитайского съезда Компартии Китая развитие экономики страны было переориентировано на расширение внутреннего потребления. Согласно принятому национальному плану по научно-техническим инновациям (2016-2020 г.г.), была поставлена цель повышения возможностей самостоятельного инновационного развития страны и построения инновационной экономики.

Стратегия «Сделано в Китае» (Made in China 2025), направленная на модернизацию промышленного потенциала страны, на развитие китайских исследований и разработок, была внедрена в 2015 году [2]. Для обеспечения устойчивого роста экономики и повышения конкурентоспособности в ближайшем десятилетии, Китай стремится закрепить за собой положение мирового лидера в высокотехнологичных сферах, в том числе в создании искусственного интеллекта.
Ключевую роль в развитии национальной инновационной системы Китая играет государство, которое координирует развитие национальной инновационной системы, содействует реформированию и развитию научно-исследовательских институтов (НИИ), расширению инновационных возможностей компаний.

На XIX Всекитайском съезде КПК Си Цзиньпин отметил необходимость неуклонного претворения в жизнь новой концепции - инновационного, согласованного, зеленого, открытого и общедоступного развития, построения модернизированного социалистического государства... [5]

Основными структурными элементами национальной инновационной системы Китая являются государственные организации (Министерство науки и технологий и др.), научный потенциал (университеты, Академии наук, научно-исследовательские институты), компании (научно-исследовательские подразделения местных компаний и зарубежных ТНК).

2. Государственные организации Китая в создании национальной инновационной системы

Министерство науки и технологий Китая координировало и финансировало работу Национальной программы исследований и разработок в области высоких технологий (программа 863). Реализованная в течение трех последовательных пятилетних планов, программа повысила общее развитие высоких технологий в Китае, потенциал научно-исследовательских и опытно-конструкторских разработок, социально-экономическое развитие и национальную безопасность. 
В 2001 году Государственный совет Китая одобрил продолжение реализации программы 863, которая играет важную роль в инновационном развитии экономики страны [4]. Программа 863 направлена на повышение инновационного потенциала в высокотехнологичных секторах экономики, на достижение прорывов в ключевых научно-технических областях, передовых рубежей мирового технологического развития.

Необходимость развития фундаментальных научных исследований привела к внедрению Национального плана по основным фундаментальным исследованиям и разработкам и Национальной программы по основным проектам фундаментальных исследований (программы «973») [3], направленных в соответствии с национальными стратегическими целями на достижение технологических и стратегических преимуществ в различных областях науки.

Государственные программы содействуют исследованиям и инновациям с целью поиска прорывов в основных пограничных областях, имеющих далеко идущее стратегическое значение (таких как наука о жизни, нанотехнологии, информационные технологии, наука о Земле и др.), способствуют всесторонним междисциплинарным исследованиям и инновационной интеграции, разработке новых идей, концепций, теорий и изобретений.

\section{3. Участие университетов и НИИ в разви- тии инноваций}

В Китае развитие системы высшего образования является важным драйвером роста экономики, усиления позиций страны в мировых рейтингах. Расширение фундаментальных и прикладных исследований в университетах и научно-исследовательских институтах открывает новые возможности для диверсификации экономики в период перехода к новому технологическому укладу, для инновационного развития страны.

Университеты

В 2017 году в Китае работало 2631 университетов, в 14971 подразделений которых исследователи занимались научно-техническими разработками. В них было выполнено в 2017 году 966780 проектов по НИОКР (в 1,4 раза больше, чем в 2013 году), опубликовано 1308110 научных статей (в 1,2 раза больше уровня 2013 года), в том числе в иностранных журналах - 390235 статей, в области науки и техники было опубликовано 45591 статей. Университетами было по- дано 277524 заявок на получение патентов на изобретения, что в 2,1 раз больше, чем в 2013 году [6].

\section{Научно-исследовательские институты}

В 2017 году в Китае насчитывалось 3547 научно-исследовательских институтов [6]. За 2005-2017 годы численность ученых, занятых исследованиями и научными разработками в Китае, составила в среднем 1206 человек на 1 млн. жителей, что больше уровня 2012 года в 1,3 раза. Фундаментальными исследованиями в Китае занимаются 7,2\% ученых, прикладными исследованиями $-12,1 \%$, экспериментальными разработками - 80,7\% ученых [6]. По наличию инженеров и ученых Китай улучшил свою позицию, в инновационном рейтинге 2017 года, поднявшись на 29 место (выше на 4 позиции).

Китайские ученые научно-исследовательских институтов опубликовали в 2016 году 426165 научных работ, на 98,9\% было дано цитирование в научных статьях [7]. В иностранных журналах в 2017 году ими было опубликовано 54500 статей [6].

В 2017 году в китайские ученые достигли 59792 крупных достижений в науке и технике, за которые получили 66 наград Национальной премии за изобретения, 170 наград Национальной научно-технической премии [6].

В 2017 году в Китае было подано 1381594 заявок на получение патентов на изобретения (в 17,2 раза больше, чем в 2002 году). Наибольшая доля патентов была подана национальными разработчиками, на долю иностранных исследователей пришлось 9,8\%. По числу поданных заявок на получение патентов Китай находился на первом месте в мире (46,3\% общего числа поданных заявок на изобретения в мире). На товарные знаки было подано 5739823 заявок (96,5\% заявок подано китайскими изобретателями), а на промышленные образцы - 628658 (97,2\% - подано резидентами) [7]. По числу заявок на патенты на изобретения на 1 млн. чел. Китай находился на 30 месте в мире. Коэффициент изобретательской активности (число патентных заявок в расчете на 1 млн. человек) составил в 2018 году в Китае 12,28 единиц.

Основные сферы деятельности, в которых были получены патенты на изобретения в Китае были следующими: цифровая связь, компьютерные технологии, электрические аппараты и оборудование, измерительные приборы, фармацевтика, металлургия, станки, химия основных 
материалов, химия пищевых продуктов, гражданское строительство.

В 2017 году по числу государственных заказов на передовые технологии Китай находился на 10 месте в мире. Однако в 2016 и 2017 годах по государственным заказам на передовые технологии Индия впервые обогнала Китай, заняв 8 место.

\section{4. Инновационная деятельность китай- ских компаний}

В Китае в 2017 году НИОКР занимались 102218 промышленный компаний (в 6 раз больше, чем в 2004 году). Их доля составляет 27,4\% от общего числа промышленных предприятий Китая. В 2017 году в промышленных компаниях Китая действовали 82667 научно-исследовательских институтов (в 4,7 раз больше, чем в 2004 году). Ими было реализовано 445029 научно-технических проектов (в 9,3 раза больше уровня 2004 года). Расходы компаний на НИОКР составили в 2017 году 173,6 млрд. долл. Компании произвели 477861 новых продуктов, ими было подано в 2017 году 320626 заявок на патенты на изобретения (в 15,7 раз больше, чем в 2004 году) [6].

\section{5. Влияние финансирования НИОКР на развитие экономики страны}

Финансирование научно-исследовательских работ является важным фактором инновационного развития стран. В 2018 году по данному показателю Китай занимал второе место в мире (после США). Китай поставил цель обогнать США по этому показателю в 2022 году. Объем финансирования НИОКР в Китае в 2018 году составил 474,8 млрд. долл., что в 2,2 раза больше уровня 2010 года [8]. В 2019 году финансирование научных исследований и разработок в Китае превысило 500 млрд. долл. и составило 22\% мировых затрат на НИОКР [9]. На фундаментальные исследования в Китае в 2017 году было затрачено 5,5\% всех средств, направленных на финансирование НИОКР, на прикладные исследования - 10,5\%, на экспериментальные разработки $-84 \%$. Объем государственного финансирования научных исследований и разработок составил в 2017 году в Китае 19,8\% затрат на НИОКР, объем финансирования НИОКР за счет собственных средств компаний - 76,5\% [7]. За 2013-2017 годы произошло постепенное уменьшение объемов государственного финансирования НИОКР в Китае и увеличение объемов собственных средств компаний, направленных на финансирование научных исследований и разработок (в 1,5 раза).
Доля затрат на НИОКР в ВВП (по ППС) страны увеличилась с 1,96\% в 2017 году до 1,99\% в 2018 году.

Основными направлениями структуры затрат на НИОКР в технологическом секторе Китая в 2015-2017 годах были следующие: информационные технологии - 22\% (13\% в 2015 году), передовые материалы - 19\% (против 15\% в 2015 году), информационно-коммуникационные технологии - 17\% (9\% в 2015 году), приборостроение $-16 \%$, военные технологии, космос, оборона $-14 \%$ (6\% в 2015 году), энергетика - 14\% (10\% в 2015 году), сельскохозяйственные, продовольственные товары - 11\% (10\% в 2015 году), автомобилестроение - 5\% (6\% в 2015 году), фармакология, биотехнологии - 6\% (4\% в 2015 году, коммерческий космос - 7\% (3\% в 2015 году), здравоохранение - 4\% (2\% в 2015 году), охрана окружающей среды - 4\% (1\% в 2015 году) [8].

Проведенный корреляционный и регрессионный анализы за 2010-2018 годы позволили выявить очень тесную взаимосвязь объема затрат на НИОКР с объемом ВВП Китая (коэффициент корреляции 0,9729), рассчитать уравнение регрессии $\left(\mathrm{y}=18.9546 \mathrm{x}_{1}+3948.0612\right)$ и сделать вывод, что увеличение объема затрат на НИОКР на 1 долл. приводит в среднем к повышению объем ВВП Китая на 18,95 долл.

\section{6. Выводы}

Проведенное исследование позволило определить, что совершенствование инновационной системы страны должно быть связано с повышением качества научно-исследовательских институтов; ростом объема расходов компаний на НИОКР; укреплением сотрудничества университетов и компаний в области НИОКР; увеличением государственной поддержки инновационной деятельности путем финансирования в виде выдачи грантов и размещения госзаказов; развитие государственно-частного партнерства в инновационной сфере; развитие венчурного инвестирования; создание налоговых льгот для всех предприятий, создающих и внедряющих инновационные технологии в производство; передача передовых технологий малому и среднему бизнесу; развитие научно-исследовательских работ в сфере больших данных, интернета вещей, облачных вычислений, робототехники; государственная поддержка патентной активности университетов и научно-исследовательских институтов; развитие инновационной инфраструктуры (технопарков, инновационных инкубаторов и др.). 


\section{Библиографический список}

1. GDP, current prices [Электронный ресурс] / World Economic Outlook (April 2019) // International Monetary Fund.- Режим доступа: http://www.imf.org/external/datamapper/NGDPD@WEO/OEMDC/ADVEC/ WEOWORLD (дата обращения: 30.04.2019).

2. Made in China 2025 [Электронный ресурс] // The State Council. The People's Republic Of China. - Режим доступа: http://english.www.gov.cn/2016special/madeinchina2025/ (дата обращения: 25.08.2019).

3. National Basic Research Program of China (973 Program) [Электронный ресурс] // Consulate General of the People's Republic of China in New York.- Режим доступа: http://newyork.china-consulate.org/eng/kjsw/std/ t1345404.htm / (дата обращения: 23.10.2019).

4. National High-Tech R\&D Program (863 Program) [Электронный ресурс] // Minestry of Science and Technology.Режим доступа: http://www.most.gov.cn/eng/eng/programmes1/200610/t20061009_36225.htm (дата обращения: 25.08.2019).

5. Reforming to Create Jobs / Doing Business 2018 // The World Bank. - Washington, 2017.- P. 128-137.

6. Science and Technology [Электронный ресурс] / China Statistical Yearbook 2018 // National Bureau of Statistics of China. - Режим доступа: http://www.stats.gov.cn/tjsj/ndsj/2018/indexeh.htm (дата обращения: 10.01.2020).

7. World Development Indicators [Электронный ресурс]// The World Bank. - Режим доступа: http://wdi.worldbank. org/table/5.13 (дата обращения 08.01.2020).

8. 2018 Global R\&D Funding Forecast [Электронный ресурс] // Industrial Research Institute.- Режим доступа: http://digital.rdmag.com/researchanddevelopment/2018_global_r_d_funding_forecast?pg=5\#pg5 (дата обращения: 23.05.2018).

9. 2019 Global R\&D Funding Forecast [Электронный ресурс] // Industrial Research Institute.- Режим доступа: https://www.rdworldonline.com/2019-rd-global-funding-forecast/ (дата обращения 17.01.2020). 